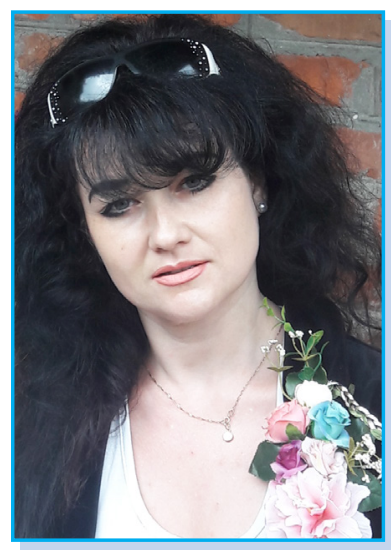

Алла Дяченко - кандидат педагогічних наук, доцент кафедри промислового дизайну і комп'ютерних технологій «Київської державної академії декоративнивно-прикладного мистецтва i дизайну імені Михайла Бойчука».

Коло наукових інтересів: художньо-промислова освіта, дизайн-освіта, національний дизайн.

diachenko.alla@ya.ru

http//:orsid.org/000-0003-4496-5931

УДК 378.13

https://doi.org/10.32405/2411-1317-2021-3-93-98

\title{
ТЕОРІЯ I ПРАКТИКА ДИПЛОМНОГО ПРОЄКТУВАННЯ СТУДЕНТІВ 3 ДЕКОРАТИВНО-ПРИКЛАДНОГО МИСТЕЦТВА І ДИЗАЙНУ
}

У статті розглянуто можливості дизайнерської діяльності з точки зору процесу проєктування і проєктної культури, яка широко використовується у дипломних роботах, при підготовці майбутніх дизайнерів та фахівців із декоративно-прикладного мистецтва. Встановлено, що діяльність дизайнера і художника декоративно-прикладної творчості різниться ступенем їх відчуження від продукту праці. 3'ясовано, що студент повинен у процесі свого дипломного проєктування продемонструвати ерудицію, глибоке знання матеріалу, літератури, мати широке уявлення про сучасний стан промислової графіки, показати вміння професійно аналізувати свою роботу, грамотно і коротко ії обгрунтувати, формулювати власні висновки, своє розуміння вирішення поставлених завдань і отриманих у процесі проєктування результатів, а не тільки тих, які були підказані і визначені керівником.

Ключові слова: дизайнер, дизайн, декоративно-прикладне мистецтво, дипломне проєктування.

Постановка проблеми. У сучасних умовах стрімких змін суспільства гостро стоїть проблема підготовки творчої, всебічно розвиненої особистості, здатної приймати самостійні рішення, знаходити нові, нестандартні шляхи вирішення поставлених перед нею завдань. Звідси різко зростає значущість змістового забезпечення процесу підготовки майбутніх дизайнерів, формування в них необхідних професійних якостей, які забезпечували б успіх у професійній і творчій діяльності. Вказана проблема $є$ актуальною і стосується сфери підготовки майбутнього митця, оскільки навіть сучасна вища школа перетворилася на багатопрофільний навчальний заклад з варіативним змістом освіти. Сьогодні значно розширюється обсяг знань, якими повинні володіти випускники ВНЗ, і разом з тим скорочується термін підготовки фахівців із кваліфікацією широкого профілю, зорієнтованого на виконання конкретних видів діяльності у сфері технологій виготовлення та оздоблення виробів різного призначення. Специфіка професійної підготовки дизайнерів потребує об’єднання вмінь, навичок трудової діяльності з формуванням рівня освіченості студентів у системі художньо-мистецьких цін- 
ностей. Актуальність роботи обумовлена тим, що виховання молодих дизайнерів, здатних надавати допомогу у розв’язанні складних науково-технічних проблем сьогоднішнього дня у цьому бачить свою відповідальну задачу і почесну місію вища школа дизайну. Удосконалення її діяльності, зростання вимог до професійної підготовки кадрів, які добре розуміють суть економічної політики, викликані постійно зростаючими масштабами нашої економіки, швидкими темпами розвитку нових технологій, науки, культури і мистецтва. Серед усього комплексу проблем удосконалення вищої школи велике значення мають всебічне підвищення якості підготовки та виховання фахівців, зміцнення зв'язків вищої школи і виробництва з суспільною практикою.

Критерієм роботи в цій галузі є рівень і якість роботи випускників - постійно ускладнюються завдання науково-технічного і соціального прогресу [1, с. 25].

Аналіз останніх досліджень та публікацій. Питанням професійної підготовки майбутнього дизайнера вивчалися у дослідженнях В. Андріяшина, І. Волощука, А. Вихруща, О. Гедвілло, В. Гетги, Р. Гуревича, В. Гусєва, П. Дмитренка, Н. Кардаш, О. Коберника, В. Кузьменка, В. Курок, В. Мадзігона, Є. Мегема, Л. Оршанського, Г. Разумної, Л. Савки, В. Сидоренка, Г. Терещука, В. Титаренко, О. Торубари, Д. Тхоржевського, В. Юрженка, М. Янцура та ін. Науковцями визначено теоретико-методологічні засади підготовки фахівців у сучасних умовах, доведено, що сутністю професійно-педагогічної підготовки є система змістовно-педагогічних та організаційно-методичних заходів, спрямованих на забезпечення готовності майбутнього дизайнера до професійної та творчої діяльності. Проте питання дипломного проєктування, ступеню самостійності дипломної роботи ще мало досліджене.

Мета статті - вивчити та проаналізувати теорію і практику дипломного проєктування студентів з декоративно-прикладного мистецтва і дизайну на різних його етапах та за наперед визначеними критеріями.

Дослідження полягало у використанні загальнонаукових методів, а саме аналітичного, індуктивного, дедуктивного і зіставного та в можливості застосувати отримані результати для теоретичного обгрунтування дипломних проєктів підготовки майбутніх дизайнерів та фахівців із декоративно-прикладного мистецтва.

Виклад основного матеріалу дослідження з повним обгрунтуванням отриманих результатів. 3 огляду на різноманіття форм дизайну в дослідницькому середовищі виникає інтерес до природи і можливостей дизайнерської діяльності, по-перше, з точки зору процесу проєктування і проєктної культури, яка широко використовується під час дипломного проєктування, а по-друге, з точки зору змісту культури сучасного суспільства, його зв'язків з природним середовищем.

Установки проєктної культури, що працює з природним середовищем, усе частіше залучаються у сферу своїх інтересів і дизайн.

Дизайн, не зважаючи на його комерційну сутність, народжується як резонанс між відкриттями і спостереженнями людини за природою і ії тонким почуттям сприйняття і реагування. Відчуття глибокої одухотвореності зовнішнього світу, що сягає корінням у старовину, зберігається без змін у культурі індустріального суспільства. У ремісничу епоху люди вірили в народження і смерть інструментів. Ця вимога зберігає свою силу і в сучасному дизайні. Ось чому необхідно, щоб у продукції дизайнерів виражалися людські почуття, яким би високим механізованим не було сучасне виробництво.

Дизайн, який зберігає за собою місію олюднення, гуманізації, життя через надання середовищу випереджальних функціональних, естетичних і екологічних якостей, у наші дні набуває ще однієї важливої ролі - він стає творцем нових ціннісних орієнтирів. Тому під дизайном мається на увазі художнє проєктування естетичного вигляду споживчих виробів, виготовлених промисловим способом [2, с. 33].

Дизайн як форма творчості є результатом розширення сфери прикладного мистецтва, його розвитку на промисловій основі. Об’єктами дизайну є утилітарні речі, які мають практичне 
значення i, крім естетичної функції, виконують безліч інших функцій, причому краса речей обумовлена практичними вимогами [2, с. 41].

Під декоративно-прикладним мистецтвом мається на увазі специфічна форма художньої творчості у сфері створення предметів побуту, яка заснована на ручній художній праці. Саме ручна художня праця служить тим вододілом, який допомагає, з одного боку, відокремити дизайн від декоративно-прикладної творчості, а з іншого - у самому мистецтві виділити дві сфери, які характеризують його сучасний стан: його ремісничу і промислову форми [3, с. 67].

Створення творів декоративно-прикладної творчості дуже трудомісткий і багатоетапний процес. Він відрізняється від праці живописця, скульптора, композитора, актора не тільки іншим матеріалом художньої творчості, але ще й іншим обсягом процесу реалізації художнього задуму [2, с. 42].

На відміну від живописців, музикантів, акторів, які користуються готовим матеріалом, художник-прикладник, перш ніж створити виріб, повинен підготувати матеріал, продумати технологію його обробки. Художнику декоративно-прикладної творчості потрібно безліч прикладних знань і навичок, без яких задумане не може бути реалізованим; він повинен пам'ятати, що між задумом і виконанням лежить тривалий і складний технологічний процес.

Якщо уявити собі весь творчий процес у вигляді трьох етапів: задуму, процесу реалізації, результату творчості, то стане ясно, що саме на проміжній стадії процесу реалізації відбуваються всі метаморфози сучасного мистецтва. Усе більше техніка починає диктувати художнику свої умови. Ці вимоги, додані до звичайного творчого процесу, усе далі відсувають самого художника від результату його праці, збільшуючи розрив між ними. Ступенем відчуження художника від продукту його праці і різниться діяльність дизайнера і діяльність художника декоративноприкладної творчості [4, с. 17].

У своїй практичній діяльності дизайнер не має можливості через складність тих предметів, які він повинен проєктувати, здійснювати весь процес самостійно. Він усього лише одна з багатьох осіб, які працюють над удосконаленням предмета. Процес реалізації загального задуму дизайнера уточнюється, розраховується цілим рядом осіб. Тим самим відбувається знеособлення предмета діяльності дизайнера. Що ж стосується прикладника, то тут процес творчості і його реалізація мають більш безпосередній зв'язок. У декоративно-прикладній творчості художник бере участь на всіх трьох етапах створення предмета. Ця участь може бути безпосередньою, а може виявлятися у рекомендаціях для виробництва, на якому освоюється запропонований ним зразок виробу. Окрім того, метою творчості художникаприкладника $є$ створення твору певного виду мистецтва, метою ж дизайнера - оновлення форм предмета відповідно до сучасних естетичних норм, удосконалення його конструктивних і функціональних характеристик. У цьому полягає основна відмінність декоративноприкладної творчості та дизайну. Але, крім відмінностей, між ними існує і особлива спадкоємність.

Довгі роки до появи дизайну декоративно-прикладна творчість створювала базу, готувала його прихід. Формування способу творчості в дизайні відбувається за рахунок накопичених декоративно-прикладною діяльністю знань і прийомів художньої творчості. Так між ними здійснився своєрідний взаємний обмін: від дизайну в декоративно-прикладній творчості приходить техніка та технологія; своєю чергою декоративно-прикладна творчість відкриває для дизайну великі художні можливості.

Культурна багатовікова традиція розрізняла потреби тіла, душі і духу, і ця різниця не втратила свого значення й сьогодні. Тому цілком природно, що дослідження національних традицій і національного мистецтва в змозі дати такий потік наукової інформації, що в підсумку не може не позначитися позитивно на розвитку сучасного мистецтва і дизайну.

Використання потенціалу етнокультури у творчості художників декоративно-прикладного мистецтва і дизайнерів завжди сприяло формуванню самобутньої держави, яка демонструє органічне існування історичних досягнень і їх використання в сучасному житті. 
Маючи вікові народні та національні традиції, декоративно-прикладне мистецтво є не тільки могутнім засобом естетичного розвитку мистецтва та художньої освіти в цілому. Воно $є$ невичерпним джерелом ідей для упровадження у професійну проєктну практику й у дипломні проєкти зокрема.

Культурна спадщина кожного народу, містить ідеї і досвід, які збагачують культуру і життя багатьох поколінь. Вона свідчить про високу культуру, традиції, життя народу, про його світосприйняття.

В історії художньої культури декоративно-прикладне мистецтво посідає особливе місце. Це - своєрідна історична пам'ять народу, в якій проявляється його зв'язок із національними традиціями, побутом, культурою. Саме національні традиції в декоративно-прикладному мистецтві стали основою для пошуків етнічної ідентифікації в період загальної інтернаціоналізації культур, формуванні глобальних технічних і естетичних пріоритетів, які утворюють споживчі цінності та впливають на розвиток мистецтва і дизайну.

Питання про традиції національного декоративно-прикладного мистецтва в сучасному дизайні стосується не тільки збереження, а й розвитку культури.

Тиражування в тій чи іншій формі вже відомого, вже створеного раніше - це поширення, а не творення нових артефактів. Проте й воно необхідне, оскільки залучає до свого широкого кола різних людей, об’єднуючи їх у процес функціонування культури в суспільстві.

Що стосується дипломних проєктів у зазначеній галузі, то вони мають ряд вимог. Студент повинен у своєму дипломному проєктуванні показати ерудицію, глибоке знання матеріалу, літератури, мати широке уявлення про сучасний стан промислової графіки, показати вміння професійно аналізувати свою роботу, грамотно і коротко ії обгрунтувати. Він зобов’язаний сформулювати власні висновки, своє розуміння вирішення поставлених завдань і отриманих у процесі проєктування результатів, а не тільки тих які були підказані і визначені керівником [5, с. 7].

Дипломник може мати іншу, ніж викладач, точку зору, що демонструє справжню, тверду підготовку фахівця. Якщо майбутній фахівець уміє науково, кваліфіковано і аргументовано відстояти свою точку зору, це говорить про розвинене самостійне мислення. При розробці дипломного комплексу він повинен проявити здатність поєднувати теоретичні знання з умінням вирішувати практичні питання. Тому однією з головних якостей при роботі над дипломним проєктом є самостійність дипломника. Ця якість під час підготовки до захисту і в майбутньому визначає його як фахівця високої кваліфікації, здатного мати свою точку зору в різних ситуаціях, робити висновки, оцінювати їх і застосовувати на практиці, тільки в цьому випадку випускники будуть фахівцями, здатними працювати практично з науковим обгрунтуванням, яке стає необхідною частиною творчої роботи [6, с. 125].

Переважно дипломне проєктування виконується за матеріалами, зібраними в період переддипломної практики в формі дипломного проєкту.

Методикою дипломного проєктування встановлюються критерії якості дипломного проєкту:

1. Актуальність теми, ії відповідність завданням соціально-економічного розвитку країни.

2. Творча самобутність і оригінальність пропонованих дизайнерських рішень.

3. Композиційна ідея і образна виразність проєктованого об’єкта.

4. Функціональна доцільність, раціональне конструктивне рішення, ступінь використання досягнень сучасних будівельних технологій і досягнень у сфері індустрії меблів, побутового обладнання, обгрунтованість вибору оздоблювальних матеріалів.

5. Характер і межі допустимого впливу на природу, її збереження і відтворення (ландшафтний дизайн).

6. Знання будівельних нормативів, ГОСТів та інших документів, що регулюють проєктну діяльність.

7. Чітка логічна послідовність, аргументація пропонованих рішень.

8. Яскраво виражений задум і розв’язання певної проблеми.

9. Високий рівень графічного і макетного виконання. 
10. Зміст проєктного матеріалу в обсязі, достатньому для повного розкриття теми та ідеї автора.

Дипломне проєктування передбачає декілька етапів.

1 ЕТАП: Вибір та затвердження теми.

2 ЕТАП: Дослідницький. Дослідницька робота по збору матеріалу і складання реферату, що містить методологічні та теоретичні позиції, висунуті автором для проєктування.

3 ЕТАП: Пошук концептуальних рішень. Консультації, мета яких - забезпечити дипломників новітньою інформацією технологічного характеру. Паралельно відбувається пошук ескіз-ідеї, уточнення загальної концепції вирішення, опрацювання варіантів.

4 ЕТАП: Стадія ескізного проєктування. Стадія розробки ескізу проєкту і концептуальної моделі, процес варіантного проєктування. Розробляється творчий задум, комплексно охоплюються містобудівні, функціонально-планувальні, конструктивні, економічні та композиційні проблеми. Створюється художній образ.

5 ЕТАП: Стадія ПРОЄКТ. Розробка проєкту в установлених масштабах. Уточнення композиції майбутнього проєкту. Обсяг дипломного проєкту загальною площею 4 м² (8-10 підрамників розміром 750x550 або 4 підрамники 1000 х 1000).

6 ЕТАП: Конструктивно-технологічний і ергономічний розділ. Застосовувані конструктивні рішення. Оздоблювальні, облицювальні матеріали. Устаткування, аспекти інженерного оснащення: вентиляція, опалення, водопостачання, каналізація, електропостачання, освітлення, декорування. Прийоми створення безпечних умов життєдіяльності.

7 ЕТАП: Економічний розділ. Завершення технічних розділів проєкту і пояснювальної записки. При необхідності показуються вузли та деталі застосовуваних конструктивних рішень. Економічне обгрунтування проєкту.

8 ЕТАП: Графічне оформлення проєкту. Графічне виконання проєкту має бути ясним, відповідати обраній темі. Усі креслення повинні мати найменування, проставлені розміри на планах і розрізах, позначки, вказівки масштабів. Брошурується пояснювальна записка, здійснюється складання макета.

9 ЕТАП: Рецензування. Дипломник спілкується з рецензентом, розповідає йому про проєкт, відповідає на питання, показує пояснювальну записку.

10 ЕТАП: Передзахист. Напередодні передзахисту керівник візує проєкт і пояснювальну записку. Нормоконтролер перевіряє відповідність оформлення пояснювальної записки вказівкам. Після цього пояснювальна записка підписується завідувачем кафедри [7, с. 154].

Успішне проходження передзахисту є підставою для допуску студента до захисту випускної кваліфікаційної роботи.

Висновки і пропозиції. Виконання дипломного проєкту є остаточним етапом підготовки молодого фахівця у вищому навчальному закладі, перевіркою рівня його професійних знань і вмінь, його підготовленості до самостійної творчої роботи. Студент-випускник повинен показати на кожному етапі дипломного проєктування високу професійну майстерність та творчі можливості відповідно до наперед визначених критеріїв. Здійснений ним дипломний проєкт виконаний на тему, затверджену радою університету і наказом ректора, на основі завдання на дипломне проєктування, складеного і виданого кафедрою з урахуванням заявок підприємств, організацій та побажань студентів-випускників.

\section{Використані джерела}

[1] В.В. Ермилова, Моделирование и художественное оформление одежды. Москва, Россия, 2000.

[2] С. М. Кожуховская, «Некоторые проблемы дизайн-образования», Вестник УМО по проф.-пед. образованию. Екатеринбург, Россия, № 1, с. 41-44, 1997.

[3] М. С. Кулик, А.В. Полухін, Положення про дипломні роботи (проєкти) випускників Національного авіаційного університету. Київ, Україна: НАУ, 2006. 
[4] Методичні рекомендації до виконання дипломної роботи на здобуття освітньо-кваліфікаційного рівня магістра для студентів 6 курсу спеціальності 8.02020701 «Дизайн» спеціалізації «Дизайн меблів» денної і заочної форми навчання. Харків, Україна, 2014.

[5] В.И. Пузанов, «Кто мы коллеги-дизайнеры?» Техническая эстетика. № 4, с. 6-8, 1991.

[6] Е.В. Ткаченко, С. М. Кожуховская, Дизайн-образование. Теория, практика, траектории развития. Екатеринбург, Россия, 2004.

[7] О.В. Трошкін, Педагогічні умови розвитку ініціативності майбутніх дизайнерів у процесі навчальнотворчої діяльності: дис. канд. пед. наук: 13.00.04. Донецьк, Україна, 2004.

\section{References}

[1] V.V. Ermilova, Modelirovanie i xudozhestvennoe oformlenie odezhdy. Moskva, Rossiya, 2000. (in Russian).

[2] S.M. Kozhuxovskaya, «Nekotorye problemy dizajn-obrazovaniya», Vestnik UMO po prof.-ped. obrazovaniyu. Ekaterinburg, Rossiya, № 1, s. 41-44, 1997. (in Russian).

[3] M.S. Kulyk, A.V. Poluhin, Polozhennja pro dyplomni roboty (projekty) vypusknykiv Nacional’nogo aviacijnogo universytetu. Kyiv, Ukrayina: NAU, 2006. (in Ukrainian).

[4] Metodychni rekomendaciyi do vykonannja dyplomnoyi roboty na zdobuttja osvitn'o-kvalifikacijnogo rivnja magistra dlja studentiv 6 kursu special’nosti 8.02020701 «Dyzajn» specializaciyi «Dyzajn mebliv» dennoyi i zaochnoyi formy navchannja. Harkiv, Ukrayina, 2014. (in Ukrainian).

[5] V.I. Puzanov, «Kto my kollegi-dizajnery?» Tehnicheskaja jestetika. № 4, s. 6-8, 1991. (in Russian).

[6] E.V. Tkachenko, S.M. Kozhuhovskaja, Dizajn-obrazovanie. Teorija, praktika, traektorii razvitija. Ekaterinburg, Rossija, 2004. (in Russian).

[7] O.V. Troshkin, Pedagogichni umovy rozvytku iniciatyvnosti majbutnih dyzajneriv u procesi navchal'notvorchoyi dijal'nosti: dys. kand. ped. nauk: 13.00.04. Donec’k, Ukrayina, 2004. (in Ukrainian).

Alla Diachenko, PhD (Pedagogy), Associate Professor at the Department of Industrial Design and Computer Technologies, Kyiv State Academy of Decorative Applied Arts and Design named after Mikhail Boychuk, Kyiv, Ukraine.

\section{THEORY AND PRACTICE OF DIPLOMA DESIGN OF STUDENTS INDECORATIVE AND APPLIED ARTS AND DESIGN}

This paper presents the possibilities of design activity from the perspective of design process and design culture, which is widely used in diploma works during the training of future designers and specialists in decorative and applied arts. It was established that both the designer`s activity and the activity of the artist of arts and crafts are distinguished by the degree of the artist's exclusion from the product of their works. It was found that a student must show erudition, deep knowledge of material and literature in their graduation works. Moreover, they need to have a broad picture of the current situation of industrial graphics, show the ability to analyze their work professionally, substantiate it in a competent and concise way, draw their own conclusions, provide the understanding of the solution to the problem and the results obtained within the design process, but not only those that have been prompted and determined by a thesis supervisor.

Key words: designer; design; arts and crafts; diploma design. 